\title{
Developing a spiritual care model for patients and their relatives in illness
}

\author{
Desenvolvimento de um modelo de cuidado espiritual \\ para pacientes e familiares no adoecimento \\ Desarrollo de un modelo de atención espiritual para los \\ pacientes y los parientes en la enfermedad
}

\section{Marta Georgina Oliveira de Góes ${ }^{\mathrm{a}}$ Maria da Graça de Oliveira Crossetti ${ }^{b}$}

\begin{abstract}
How to cite this article: Góes MGO, Crossetti MGO. Developing a spiritual care model for patients and their relatives in illness. Rev Gaúcha Enferm. 2020;41(esp):e20190150. doi: https://doi.org/10.1590/19831447.2020.20190150
\end{abstract}

a Hospital de Clínicas de Porto Alegre (HCPA), Unidade de Hemodinâmica e Leitos Vascular. Porto Alegre, Rio Grande do Sul, Brasil.

b Universidade Federal do Rio Grande do Sul (UFRGS), Escola de Enfermagem, Departamento de Enfermagem Médico-Cirúrgica. Porto Alegre, Rio Grande do Sul, Brasil

\section{ABSTRACT}

Objective: To develop a spiritual care model for patients and their relatives in illness.

Methodology: A qualitative study that uses Symbolic Interactionism as theoretical framework, and the Grounded Theory designed by Charmaz as methodological framework. Semi-structured interviews were performed with 10 participants, and the Model was validated by an expertise group, from march to may 2016, at a University Hospital in the South of Brazil. When analyzing the data, the following codifications were made: initial, focalized, axial and theoretical.

Results: The categories that structured the Model were the following: Situating spirituality in their daily lives; Exercising spirituality in life; Perceiving the role of the nursing team in spiritual care; Identifying the manifestations of spiritual needs; Placing spirituality as a priority in care and Re-signifying the illness process.

Conclusion: Developing the model has enabled us to achieve a conceptual understanding and interpretation of spiritual care in nursing and to draw up the connections among the nursing team, the patients and their relatives.

Keywords: Nurse's role. Spirituality. Nursing care. Nursing models. Nursing. Grounded Theory.

\section{RESUMO}

Objetivo: Desenvolver um modelo de cuidado espiritual para pacientes e familiares no adoecimento.

Metodologia: Estudo qualitativo que utilizou como referencial teórico o Interacionismo Simbólico e metodológico a Teoria Fundamentada em Dados por Charmaz. Realizadas entrevistas semiestruturadas com 10 participantes e validação do Modelo por um grupo de expertise, de março a maio de 2016 em Hospital Universitário do sul do Brasil. Na análise dos dados foram realizadas as codificações: inicial, focalizada, axial e teórica.

Resultados: As categorias que estruturaram o Modelo foram Situando a espiritualidade no seu viver; Exercitando a espiritualidade na vida; Percebendo o papel da equipe de enfermagem no cuidado espiritual; Identificando as manifestações das necessidades espirituais; Colocando a espiritualidade como prioridade no cuidado e Ressignificando o adoecimento.

Conclusão: A construção do modelo possibilitou uma compreensão e interpretação conceitual sobre o cuidado espiritual na enfermagem e delineadas as conexões entre a equipe de enfermagem, os pacientes e familiares.

Palavras-chave: Papel do profissional de enfermagem. Espiritualidade. Cuidados de enfermagem. Modelos de enfermagem. Enfermagem. Teoria fundamentada.

\section{RESUMEN}

Objetivo: Desarrollar un modelo de atención espiritual para los pacientes y los parientes en la enfermedad.

Metodología: Estudio cualitativo que utilizó como marco teórico el Interaccionismo Simbólico; y como marco metodológico la Teoría Fundamentada en Datos diseñada por Charmaz. Se realizaron entrevistas semiestructuradas con 10 participantes y el Modelo fue validado por un grupo de expertos, entre marzo y mayo de 2016, en un Hospital Universitario del sur de Brasil. Al analizar los datos, se realizaron las siguientes codificaciones: inicial, enfocada, axial y teórica.

Resultados: Las categorías que estructuraron el Modelo fueron las siguientes: Situar la espiritualidad en su vida; Ejercitar la espiritualidad en la vida; Percibir el rol del equipo de enfermería en la atención espiritual; Identificar las manifestaciones de las necesidades espirituales; Priorizar la espiritualidad en la atención y Resignificar la enfermedad.

Conclusión: La construcción del modelo permitió comprender e interpretar conceptualmente la atención espiritual en la enfermería y el diseño de las conexiones entre el equipo de enfermería, los pacientes y los parientes.

Palabras clave: Rol de la enfermera. Espiritualidad. Atención de enfermería. Modelos de enfermería. Enfermería. Teoría fundamentada. 


\section{口INTRODUCTION}

The illness process causes different degrees of physical, emotional, spiritual and social changes that affect patients and their families. In these moments the importance is perceived of adding active listening, emotional and spiritual support to the nursing care, which are elements of spiritual care and enable patients and their families to mobilize ways of coping and thus cope with the challenges imposed by the disease ${ }^{(1)}$.

Understanding the attributes of spiritual care requires understanding the concepts of spirituality and religiosity. Spirituality refers to the internal dimension of the individual, its connection with the sacred and the transcendent; religiosity is an external form of expression of spirituality, as it encompasses an organized system of beliefs, rituals and practices with which the individual identifies and relates to a higher being ${ }^{(2)}$.

Spiritual care involves promoting connection with others and the community, or further investigating on spiritual needs, religious beliefs or of other nature ${ }^{(2)}$. Spiritual needs can be expressed in the latest decisions, reflection on the meaning of life, plans for the future, anxiety, denial, Ioneliness, requests for emotional support, family relationships, religious needs, being able to speak and getting assurances that no additional suffering will result ${ }^{(3)}$.

These can still be identified when the patient expresses interest in matters related to spirituality, demonstrate reverence for devotional articles (images of saints, rosaries and/or scapulars, protective guides - used in African-based religions, among others), celebrate religious dates, and/or conduct existential questionings about the afterlife ${ }^{(4)}$. Although the spiritual needs have psychological aspects, human nature is a complex biopsicosociospiritual, in which these aspects are interconnected and, commonly, their manifestations are inter-related ${ }^{(3)}$. Thus, the nursing staff needs to be able to identify and provide spiritual care and, for this, one of the possible ways can be applying models.

In the literature review preceding the study ${ }^{(1)}$ that originated this article 22 models of spiritual care were found, seven directed to end-of-life care. In five studies the goal was related to serving groups whose beliefs and values were deeply linked to their religions. Another seven aimed at training health professionals in spiritual care, in addition to teaching and research. The remaining three models were characterized as follows: one model for the chaplains, another for the training of social workers in spiritual care and the last one directed to the preparation of nurses for providing spiritual care to patients in primary care.

Among the studies analyzed in Brazil, three models of spiritual care were identified: the first was performed with cancer patients to support the work of nurses ${ }^{(5)}$, the second is the one found in this article ${ }^{(1)}$ and the third one was developed for adolescents with HIV/SIDA living the transition to adulthood ${ }^{(6)}$.

The models of spiritual care under analysis were the object of studies by researchers from different cultural contexts and areas of knowledge, applied in different care settings. Although some of them had the participation of nurses, they were not built up from the lives and experiences of the nursing team in spiritual care in our country ${ }^{(1)}$.

In an international consensus ${ }^{(2)}$ carried out to improve care practices with emphasis on the spiritual dimension, it was recognized that health care models should honor the dignity of all individuals (patients, families and caregivers) and that they should be focused on relationships with individuals and communities.

A nursing care model has a framework of ideas and concepts that can show variants in their conceptions, besides having a theoretical-philosophical framework that guides the nursing care $^{(7)}$.

Thus, care models are needed that integrate the fulfillment of spiritual needs with other nursing care practices, adapted to the Brazilian culture and developed from the experiences of nurses and nursing technicians. From this findings it is questioned if it is possible to develop a model of spiritual care for patients and their families in coping with illness situations from the experiences of nurses and nursing technicians.

Thus, the objective is to develop a spiritual care model for patients and their relatives in illness.

\section{- METHOD}

This study of a qualitative nature used Symbolic Interactionism $(\mathrm{SI})^{(8)}$ as its theoretical reference and the Grounded Theory $(\mathrm{GT})^{(9)}$ as its methodological framework, and it was originated from a doctoral thesis ${ }^{(1)}$.

In its theoretical perspective SI understands society, reality and the individual as established through interaction and thus relies on language and communication. It still assumes that interaction is dynamic and interpretive, it is about how people create, represent and change meanings and actions. Constructivist GT in a symbolic interactionist perspective provides an interpretive image of the studied world and not its faithful reproduction ${ }^{(9)}$.

Symbolic Interactionism is grounded in basic ideas, which describe the nature of the following themes: human groups, objects, human being, and human action. Still relevant are the concepts of symbol, self, mind, assuming the role of the other, language, social interaction and in the context of this study included that of the family (Chart 1). 
The research was conducted at a university hospital in the South of Brazil, accredited by the Join Commission International, from march to may 2016, with the participation of six nurses and four nursing technicians from the Adult Intensive Care Units, Pediatric Inpatient Unit, Surgical Unit, Palliative Care, Pediatric Oncology, Clinical Admission and Hemodynamics.

The selection of the participants by convenience included those with one or more years of experience in the institution and excluded individuals with no performance in direct care to the patients. The nurses were chosen at random and the nursing techniques indicated by their care practices were aggregated by elements of spirituality.

The experts, in a number of four, belong to the study center on the Center for Interdisciplinary Studies on Health and Spirituality (Núcleo de Estudos Interdisciplinares em Saúde e Espiritualidade, NEISE) of the institution and did not participate in the initial data collection. These validated the "Preliminary Spiritual Care Model" (Modelo de Cuidado Espiritual Preliminar, MCEP), in a meeting whose synthesis on the characteristics of the model was obtained after a meeting lasting 2 hours 8 minutes.

\begin{tabular}{|c|c|}
\hline Concepts & Definitions \\
\hline Human groups & $\begin{array}{l}\text { Constituted by human beings involved in actions, that is, activities that they perform in their lives } \\
\text { with other individuals or in representing groups and organizations }{ }^{(8)}\end{array}$ \\
\hline Objects & $\begin{array}{l}\text { They were classified into three categories: physical, social and abstract objects. The nature of an } \\
\text { object or of all objects consists of the meaning ascribed to it/them by its owner }{ }^{(8)}\end{array}$ \\
\hline Human being & $\begin{array}{l}\text { It indicates that the individual, as an acting organism, does not respond to others solely on a non- } \\
\text {-symbolic level, but emits signals to others and interprets signals from them }{ }^{(8)}\end{array}$ \\
\hline Human action & The individual's ability to make indications for themselves and distinguishes their action ${ }^{(8)}$ \\
\hline Symbol & $\begin{array}{l}\text { It represents the central concept of the SI and, in its omission, the interaction between human } \\
\text { beings becomes unfeasible. Symbols are considered as social objects used by the actor for repre- } \\
\text { sentation and communication }{ }^{(8)}\end{array}$ \\
\hline Self & $\begin{array}{l}\text { The self has two phases: The "I" and the "me". In the first phase, the "I" refers to the individual as a } \\
\text { subject, highlighting the characteristics, spontaneous dispositions, not socialized. In the second, } \\
\text { the "me" comprises the individual as a social object, arising from the interaction" }{ }^{(8)}\end{array}$ \\
\hline Mind & $\begin{array}{l}\text { The "mind" is an activity that points to the self. The mental process is considered as the symbolic } \\
\text { interaction through which the individual handles the symbols and actively communicates with } \\
\text { the self(8) }\end{array}$ \\
\hline $\begin{array}{l}\text { Assuming the } \\
\text { other's role }\end{array}$ & It involves understanding the reasons and ways for which people act in a certain way ${ }^{(8)}$ \\
\hline Language & $\begin{array}{l}\text { The use of the word in the dialogs and symbols, such as gestures, behaviors and actions, have social } \\
\text { meanings, established in interactions and that become a symbol when they acquire meaning for } \\
\text { those who use them }{ }^{(8)}\end{array}$ \\
\hline Social interaction & $\begin{array}{l}\text { Mutual social action, involving symbolic communication and interpretation for the actions of others, } \\
\text { considering in the organization of our actions the opinion of others }{ }^{(10)}\end{array}$ \\
\hline Family & $\begin{array}{l}\text { Seen not only as a biological and natural unity, but as a social, therefore, interactional space where } \\
\text { each event is lived from symbolically constructed meanings }{ }^{(11)}\end{array}$ \\
\hline
\end{tabular}

Chart 1 - Basic Ideas of Symbolic Interactionism 
Semi-structured and intensive interviews, characterized by broad and open non-value questions, also contemplated the identification data: age, time in the profession and performance in the study institution. The interviews and the meeting with the expertise group were held in the facilities of the study institution, and they were audio-recorded.

Data analysis was performed using the initial, focused, axial and theoretical coding proposed by the constructivist $\mathrm{GT}^{(9)}$. Throughout the stages, the memos were written, which recorded comparisons and connections, and indicated the questions and directions to follow ${ }^{(12)}$.

The initial coding occurred after the transcription of each interview and after detailed reading, in which the words, lines or data segments were fragmented. As interviews were transcribed and inserted into the Qualitative Solutions Research NVivo 11.0 software, the initial classifications were elaborated using the same words of the interviewees to name the subcategories ("codes in vivo").

The focused coding used the most significant initial codes or initial subcategories to classify, synthesize, integrate, and organize data into subcategories and initial categories.

The axial coding specified the properties and dimensions of a category by relating categories to subcategories and regrouping data that was fragmented during the initial coding to give coherence to the emerging analysis. In this categorization, the three components were obtained: assumptions, actions and actions results.

In the theoretical coding, the categories that emerged from the axial coding were identified, the relations between them and the recognition of the central category were established. Soon afterwards, the scope of the theory was integrated and delimited, which corresponded to the MCEP, who had their assumptions validated at the meeting with the expertise group, constituted by four NEISE members and by one non-NEISE participating nurse as an observer.

The study was approved by the ethics committee of the Universidade Federal do Rio Grande do Sul, under opinion No.1,385,054 $4^{(1)}$. The participants signed the Free and Informed Consent Form and their codenames were chosen by the researcher, in line with the life stories reported by the participants, from the denominations of Mary, Mother of Jesus, identified by different names according to the place and the circumstances in which she was venerated.

\section{口ESULTS AND DISCUSSION}

The study participants were between 36 and 60 years old. Among the nurses, the period of professional practice ranged from 13 to 40 years; and working at the institution, from nine to 38 years. The nursing technicians practiced the profession for 18 to 35 years and worked in the institution between seven and 16 years.

From the integration of the categories and subcategories and the validation by the MCEP expertise group, the central category emerged Re-signifying the IIIness Process (REFIP), Spiritual Care Model, displayed in Chart 2, which expressed the assumptions about spirituality, the actions resulting from the nursing care offered by the nursing staff to patients and their families.

The assumptions identified in Situating spirituality in your life encompass the trajectory of nurses and nursing technicians' spirituality as a fundamental necessity for the care of themselves and others. Spirituality structures their beliefs, regardless of religious affiliation; it provides a sense of well-being, composes their daily habits and mediates the search for their personal truths.

[...] spirituality is a security [...] a source where we re-feed ourselves, it gives us energy, comfort, relief, no matter what kind of beliefyou have, it brings serenity to some of the things you need to face in life [...] (Our Lady of Carmel)

[...] I see spirituality as a daily thing, that we have to exercise the quality of our faith which is spirituality, different from religion (which is) a belief, that depending on religion, imprisons your thoughts a lot and spirituality does not, it liberates you, you end up discovering your own truths and it's something we do daily [...] (Our Lady of the Navigators)

[...] spirituality, for me, is a human need, let's say, to take good care of oneself [...] (Our Lady of Lourdes)

The training time of the nurses and nursing technicians, combined with their life trajectories in spirituality, can be considered preponderant in the way of understanding and doing nursing. The participants demonstrated security and familiarity with spiritual care associated with the usual nursing practices. The practice of nursing was decisive in improving these concepts, as the suffering experienced strengthened the need for participants to seek other forms of comfort for themselves and others through spirituality. A study related to the concept of spiritual care has identified that the perception of transcendence, self-knowledge, religious affiliation, professional commitment, sensitivity, and intentionality characterize the elements that precede spiritual care ${ }^{(13)}$. The meanings, symbols and actions related to spiritual care displayed themselves in different ways for the participants, but were structured from the interaction with others, namely family or society. Thus, the language used by the participants demonstrated the meaning attributed to spirituality as a source of security and serenity. 


\begin{tabular}{|c|c|}
\hline \multicolumn{2}{|c|}{$\begin{array}{l}\text { Central category } \\
\text { Re-signifying the Illness Process (REFIP) - Spiritual Care Model }\end{array}$} \\
\hline Categories & Subcategories \\
\hline Assumptions & \multirow{2}{*}{$\begin{array}{l}\text { Recognizing spirituality as a necessity and a complement } \\
\text { Walking in spirituality }\end{array}$} \\
\hline Situating spirituality in your life & \\
\hline Exercising spirituality in life & $\begin{array}{l}\text { Practicing spirituality in your own way } \\
\text { Realizing spirituality as a life option } \\
\text { Respecting beliefs }\end{array}$ \\
\hline Actions & \multirow{2}{*}{$\begin{array}{l}\text { Identifying forms for coping with suffering } \\
\text { Happening: the time to meet the needs }\end{array}$} \\
\hline $\begin{array}{l}\text { Identifying the manifestations of the } \\
\text { spiritual needs }\end{array}$ & \\
\hline Realizing the role of the nursing staff & $\begin{array}{l}\text { Advocating the patient's rights and for the sake of the profession } \\
\text { Talking about spirituality } \\
\text { Caring for the process of death and dying } \\
\text { Preparing the nursing staff } \\
\text { Limiting care for personal, organizational, and religious beliefs }\end{array}$ \\
\hline Results & \multirow{2}{*}{$\begin{array}{l}\text { Welcoming the patient and their families } \\
\text { Using integrative practices } \\
\text { Praying with the patient } \\
\text { Comforting through spirituality } \\
\text { Continuing to believe everyday }\end{array}$} \\
\hline Prioritizing spirituality in care & \\
\hline
\end{tabular}

Chart 2 - Re-signify the IIIness Process - Theoretical model of spiritual care

Source: Research data, 2016.

In its symbolism, language has expressed the description of abstract objects (faith, religion, beliefs) and what has been directed towards each other in the social interaction ${ }^{(8,10)}$. The participants' narratives demonstrated how their beliefs were structured from their experiences in spirituality with the discovery of their own truths, whether through a religion or an activity that brought well-being. This characterizes the nature of human action in which the human being confronts the world and interprets it to act ${ }^{(8)}$.

In Exercising spirituality in life, the participants described spirituality as an integral part of their lives under the form of the ethical conduct and social duties of helping the other. The chosen ways to practice spirituality were respect for the beliefs of the patients and family members, demonstrating their willingness to answer their questions about spirituality. Increasing intuition was also associated with spiritual practices, caring, and tolerance.
[...] I am a spiritist, I take courses, I try to work it in my family [...] to be a spiritist, having taken the Reiki course, everything, I believe in energy, this is something that is part of my daily life [...] (Our Lady of Conception)

[...] / say a prayer before entering the unit [...] / believe we have a mission [...] I have to learn from them [the children] and if my role there is to help them cope with this (the disease) I have to be prepared [...] (Our Lady of Glory)

[...] it influences my ethical living process, in relation to the patient's belief, my belief does not have to interfere [...] I have to communicate with the patient in their communication channel, their belief, always respecting whether they believe in God or not, the inner resources are structured in their belief [...] (Our Lady of Graces)

[...] it happens [intuition] all the time [...] after studying hard, having these contacts [with other religious philosophies] I 
started to hear a lot more about my intuition, how shall I approach [the patients] and sometimes this comes in an insight [...] (Our Lady of Glory)

In this category, it was identified that the exercise of spirituality took place by different religions, besides the adoption of integrative practices. Understanding how nurses and nursing technicians build up their practices is to "take on the role of the other", in order to understand the way to offer spiritual care in line with the desire, beliefs and values of the patients and their families. The ethical conduct, the fulfillment of social duties on helping others and the appreciation of intuition were also associated with the development of spirituality. Thus, we have the self in its me phase acting in the world by conducting its interaction with the others ${ }^{(8)}$.

Nurses with moderate to favorable levels of spirituality perception and spiritual care had an adequate degree of competence to provide such care, and a significant correlation was found between spiritual well-being and the attitude toward spirituality and the competence for spiritual care ${ }^{(14)}$. Thus, individuals who are clear about the fundamentals and exercise of their own spirituality tend to value and feel able to approach the theme with patients, a statement corroborated in a study that positively correlated addressing spiritual and/ or religious issues with high levels of personal religiosity, and as the lower these levels there was an association with the delay in addressing the subject with the patients ${ }^{(15)}$.

In the actions recognized in Realizing the role of the

nursing staff in spiritual care we find the elements that make up the exercise of nursing in spiritual care. The participants highlighted the importance of defending patients' rights in relation to their beliefs and values.

[...] Except that we have these barriers, difficulties, prejudices to work [spirituality] within the hospital, nursing needs to defend this, advocate for the patient, defend their interests [...] we need to advocate for our own profession [...] because for this patient it can be important and he needs to feel welcomed by someone wanting to know his belief [...] (Our Lady of Carmel)

[...] / think our role is fundamental [...] we spend most of the time with the patient [...] even in informal conversations we capture what the family member, the patient believes in. Talking about what they believe we can do to improve, to remember the things they did in the hard times [...] (Our Lady of Lourdes)

[...] the professionals are not there to indoctrinate, they are there to respect and to work with the person's inner resources, speak in the person's communication channel because comfort is for the person. I am a professional [nurse], the reasoning is mine, I have to understand that all that agony, anguish belongs to the moment of the patient, of that family and my role is to understand and assist in the comfort issue [...] (Our Lady of Graces)

[...] Look, l've already said a prayer with the family... when they are sedated or already very symptomatic [...] / see the child, the family, I say goodbye, I appreciate the opportunity to live together, experience, to be around at that moment because we live with them a long time [...] (Our Lady of Glory)

[...] Then I told them (family members), that the patient will hear [...] hearing is the last sense the patient loses, so take the opportunity to speak, to say that you love them, to thank [...] (Our Lady Mother of God)

The participants highlighted the role of advocating the patients' rights in respect of their beliefs and of the profession. Patients valued nurses who were able to establish personal connections, to act as their advocates and to respond to their individual needs(16).

Most nurses who consider spiritual care as a nursing competence, highlighting the importance of an interdisciplinary approach, due to the complexity related to addressing the spiritual dimension $^{(17)}$.

Welcoming the family members was also highlighted, because the attention given to the patient, especially those critically ill, diverts the focus of the family forgetting that both make up a nucleus of care. At this point, the importance of talking to the family members and preparing them for their loved one's departure is highlighted.

A study with families of children and adolescents under palliative care evidenced the responsibility of the nurses to know the ways in which families seek to restructure in the face of a worsening disease. Thus, recognizing the suffering, accepting the questions and performing the necessary orientations may help to restore the balance of the family system, so as to have an impact on the elaboration of grief after the patient's death ${ }^{(18)}$.

The family is a group of individuals in symbolic interaction, assuming the role of a link between the patient and the health team, bringing their meanings to the lived situation. Thus, the nursing staff are the "other signifiers" whose role is to interact and favor the understanding of the meanings found in the illness process and its consequences.

\section{And in Identifying the manifestations of spiritual}

needs we find the various manifestations of the spiritual needs and the moments in which they are identified. 
[...] usually when the patient is anxious, when that pain does not go away, it is not a physical pain, it is a pain that is being exteriorized [...] when the patient starts to get depressed, not wanting anything else, gave up the cares [...] (Our Lady of the Navigators)

[...] before the anamnesis, the reception [in] our sector [palliative care unit] begins, we welcome the family before, and when they come, we take an approach to the current state of the patient, prognosis, perspectives and there already comes this question of spirituality [...] when the patient gets more critical [...] then the family wants the priest, the pastor [...] (Our Lady of Graces)

Nurses and nursing technicians reported the various ways in which the spiritual needs were displayed, which sometimes were somehow confused with biopsychosocial aspects. A study indicated that the nurses were able to identify the patients'spiritual needs and strategies to meet them, but further research is needed since spiritual suffering may manifest as psychological symptoms such as anxiety, anguish, and depression ${ }^{(3)}$. Spiritual needs are also characterized as being recognized as a person to the end of life, the need for the truth, reinterpreting life, recognizing the meaning of life, hope, and religious expression ${ }^{(19)}$.

Thus, the nature of the human being is manifested when emitting signals for the others (needs expressed by the patients) and interpreting the coming signals (participants' perception on the meanings of these needs), and the nature of human action, which can be guided by the past, motivations, emotions of both patients and nursing staff(8).

In the results identified in Prioritizing spirituality in care the ways in which spirituality has been added to careto-care are described.

[...] in the area of the ICU you talk about it (religious support), there is a relationship of trust [...] we have extended the schedule so that the family can be with the patient at all times [...] we close the curtain, and let the family stay with the patient and the religious mentor [...] I talk a lot about the things they believe in. Many times, what the patient believes in is what will give them strength to keep fighting [...] (Our Lady of Lourdes)

[...] I have already applied Reiki to them or because of pain, for not being able to sleep, when they [the patients] call me, when they are going to do a procedure I say a prayer too [...] teaching relaxation exercises, something from my Buddhist practice, using music, saying a prayer [...] (Our Lady of Glory)
[...] sometimes I say a prayer, I ask the patients if they have prayed today... when the family members leave I invite them [to pray] if I have the opportunity to be alone, this is the time when I talk to the patient, God is here! If I can't do that, if the family member doesn't go out, I do it out there, but that moment when they reach the end line, it is the moment I think they need to be connected (with God) [...] (Our Lady Mother of God)

In this category, the preoccupation with receiving the requests for religious care, respecting beliefs and values prevailed. Studies conducted with palliative care patients and health professionals have identified spiritual needs and interventions similar to those described by the participants in this study $20-21)$.

Symbolic interaction in assuming the place of the other is responsible for the effective performance of diverse activities, including empathizing, assisting and protecting ${ }^{(10)}$.

Using integrative practices such as Reiki, massage and relaxation has been described as alleviating the physical, psychic and spiritual suffering. Reiki practice was effective in decreasing anxiety and pain intensity, as well as in decreasing blood pressure and increasing immune cells in the analyzed subjects ${ }^{(22)}$.

Prayer practice with patients and family members was also described by participants as frequent and performed whenever requested. A study conducted with 445 nurses found that $90 \%$ of the participants believed it was appropriate to take the initiative to address issues related to spirituality and/or religiosity, as well as to pray with the patients under certain circumstances or at any time ${ }^{(23)}$.

Thus, the central category Re-signifying the Illness

Process (REFIP) outlined the assumptions of the spiritual care offered to the patients and families in coping with illness situations, the actions and results supported by metaparadigms and in the concept of spiritual care. Still, it also made it possible to have a new understanding of the moment lived by the patient and their family members, favoring the elaboration of a meaning in the midst of pain and fear, alleviating guilt, regaining hope, reminding the patient of their dreams and desires and offering care to the family in their suffering.

The REFIP was developed for the nursing team to develop skills and to exercise spirituality in their practice; however, due to its characteristics it may also be used with patients who do not have religious beliefs. The model can also be understood as an ethical living model, as it is used as a possibility to lead a personal life. 
The assumptions of the spiritual care model are interrelated with the four nursing metaparadigms, basic concepts that underlie its practice, such as: nursing, environment/ society, human being, health/disease; as well as other pertinent ones. The REFIP(1) metaparadigms plus the concept of spiritual care are displayed in Chart 3.

In addition, the construction of the theoretical model (Figure 1) enabled the development of a practical spiritual care model that can be used by professionals in areas other than nursing.

\section{FINAL CONSIDERATIONS}

The development of the model made it possible to understand the way in which the participants' life experience in the different religious aspects, based on the family values and on the personal search for answers, gradually led to incorporating spirituality into their practices.

The REFIP - Spiritual Care Model was built up from the assumptions made explicit in the categories Situating spirituality in your life and Exercising spirituality in the life and actions of nurses and nursing technicians in spiritual care highlighted in Identifying the manifestations of the spiritual needs and Realizing the role of the nursing staff, and the results characterized by the care priorities are in Prioritizing spirituality in care.

Among the limitations, the need is recognized to conduct research studies that apply the model in other care settings to bring new perspectives on the theme, thus expanding its scope.

The study's contribution to the nursing body of knowledge is to offer a model of spiritual care built up from the experience of the nursing team in different care settings. In addition to giving visibility to nursing practices, which return to their origin, taking care of human beings in their complexity and the fundamental role of advocating for the rights of the patients and their families.

In teaching, it is believed that the foundations and practices associated with spiritual care can be incorporated across the curriculum of all areas of knowledge, especially nursing.

The development of new studies applying the REFIP model will proceed with its construction, which is necessary to verify its applicability and to adjust it when indicated.

\begin{tabular}{|c|c|}
\hline Metaparadigms & Definitions \\
\hline Human being & $\begin{array}{l}\text { A multidimensional being (physical, emotional, social and spiritual) that is being cared and provides } \\
\text { care, with beliefs and values influenced by their culture. The family makes up the universe of the } \\
\text { being cared for. }\end{array}$ \\
\hline Nursing & $\begin{array}{l}\text { Profession in which the essence is the care for the human being in its entirety from conception to } \\
\text { death, with technical, ethical and aesthetic knowledge applied by nurses and nursing technicians, } \\
\text { in line with their beliefs and values, and is influenced by the care-related culture scenarios. }\end{array}$ \\
\hline Environment & $\begin{array}{l}\text { Place where the human beings live or stay during periods of their life that contemplates physical } \\
\text { (urban and rural) and non-physical (social and historical context) aspects, being influenced by the } \\
\text { cultural aspects of the human group where they are found. In the context of this study, it is the } \\
\text { local hospital, with its own culture permeated with rules of how to be and behave for all who work } \\
\text { and remain in this environment. }\end{array}$ \\
\hline $\begin{array}{l}\text { Health } \\
\text { and disease }\end{array}$ & $\begin{array}{l}\text { Process lived by human beings and influenced by biological, emotional, economic, social, cultural, } \\
\text { spiritual and environmental dimensions. }\end{array}$ \\
\hline Spiritual care & $\begin{array}{l}\text { Care aimed at meeting the spiritual needs in their different manifestations, which can be identified } \\
\text { and met by the nursing team sensitive to the moment lived by the person cared for and their family. }\end{array}$ \\
\hline
\end{tabular}

Chart 3 - Metaparadigms of the spiritual care model

Source: Research data, 2016. 


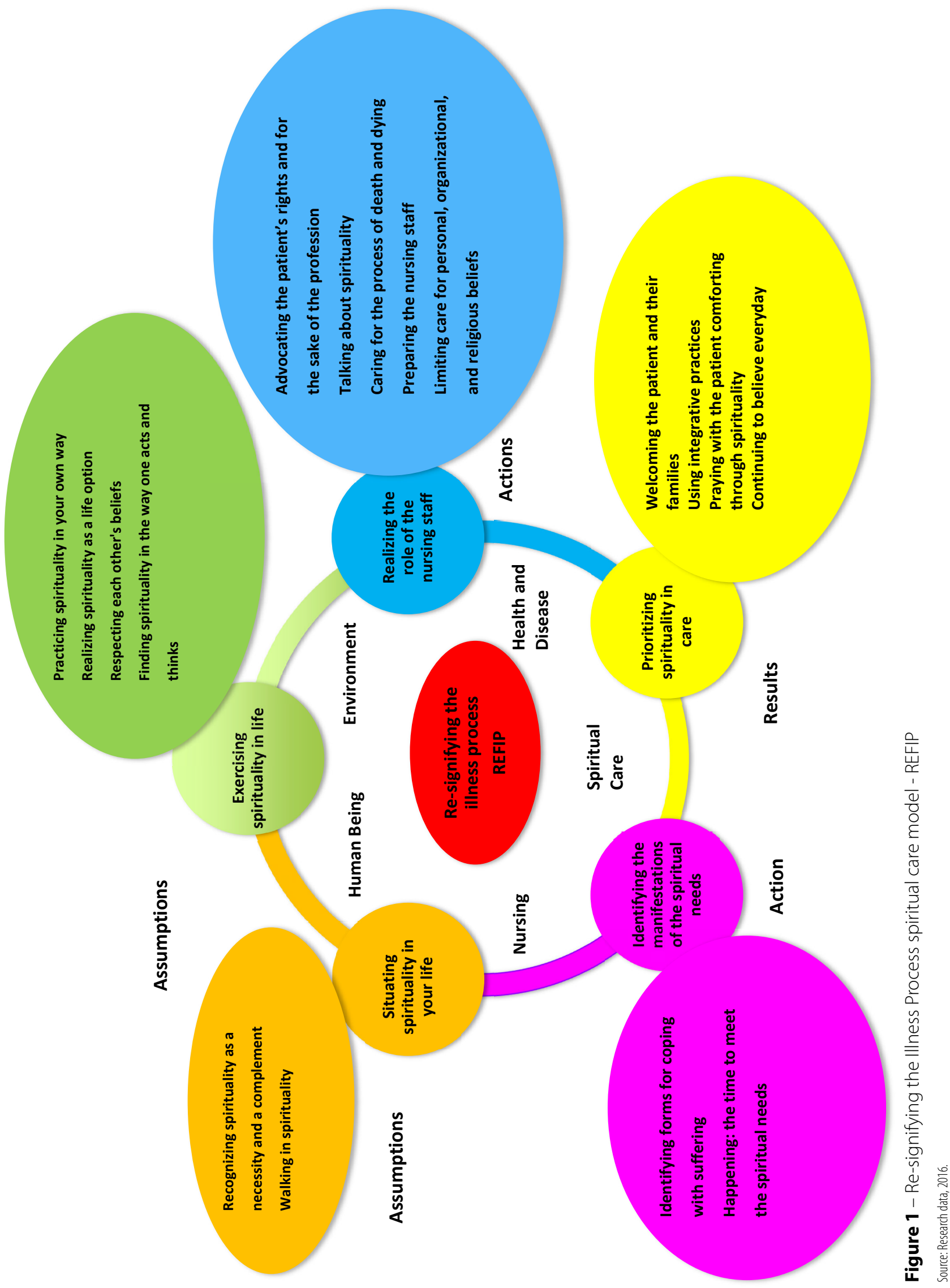




\section{QREFERENCES}

1. Góes MGO. Ressignificando o adoecimento: modelo de cuidado espiritual [tese]. Porto Alegre (RS): Universidade Federal do Rio Grande do Sul; 2016.

2. Puchalski CM, Vitillo R, Hull SK, Reller N. Improving the spiritual dimension of whole person care: reaching national and international consensus. J Palliat Med. 2014;17(6):642-56. doi: https://doi.org/10.1089/jpm.2014.9427

3. Nixon AV, Narayanasamy A, Penny V. An investigation into the spiritual needs of neuro-oncology patients from a nurse perspective. BMC Nurs. 2013;12:2. doi: https://doi.org/10.1186/1472-6955-12-2

4. Timmins F, Caldeira S. Assessing the spiritual needs of patients. Nurs Stand. 2017;31(29):47-53. doi: https://doi.org/10.7748/ns.2017.e10312

5. Araújo MAM. 0 cuidado espiritual: um modelo à luz da análise existencial e da relação de ajuda [tese]. Fortaleza (CE): Universidade Federal do Ceará; 2011.

6. Brum CN. Modelo teórico de cuidado espiritual ao adolescente vivendo com HIV/aids na transição para a vida adulta [tese]. Porto Alegre (RS): Universidade Federal do Rio Grande do Sul; 2017.

7. Favero L, Wall ML, Lacerda MR. Conceptual differences in terms used in the scientific production ofBrazilian nursing. Texto Contexto Enferm. 2013;22(2):53442. doi: https://doi.org/10.1590/S0104-07072013000200032

8. Blumer H. Symbolic interactionism: perspective and method. Berkeley: University of California Press; 1969.

9. Charmaz, K. A construção da teoria fundamentada: guia prático para análise qualitativa. Porto Alegre: Artmed; 2009.

10. Charon JM. Symbolic interactionism: an introduction, an interpretation, an integration. 9th. ed. New Jersey: Pearson/Prentice Hall; 2007.

11. Angelo M. Com a família em tempos difíceis: uma perspectiva de enfermagem [tese]. São Paulo (SP): Universidade de São Paulo; 1997.

12. Crossetti MGO, Goes MGO, Brum CN. Application of Constructivist Grounded Theory in nursing research. Qualitative Rep. 2016 [cited 2019 Jan 30];21(13):4853. Available from: https://nsuworks.nova.edu/tqr/vol21/iss13/5/

13. Ramezani M, Ahmadi F, Mohammadi E, Kazemnejad A. Spiritual care in nursing: a concept analysis. Int Nurs Rev. 2014;61(2):211-9. doi: https://doi. org/10.1111/inr.12099

14. Azarsa T, Davoodi A, Markani AK, Gahramanian A, Vargaeei A. Spiritual wellbeing, attitude toward spiritual care and its relationship with spiritual care competence among critical care nurses. J Caring Sci. 2015;4(4):309-20. doi: https://doi.org/10.15171/jcs.2015.031
15. Taylor EJ, Gober-ParkC, Schoonover-Shoffner K, Mamier I, Somaiya CK, Bahjir K. Nurse opinions about initiating spiritual conversation and prayer in patient care. J Adv Nurs. 2018;74(10):2381-92. doi: https://doi.org/10.1111/jan. 13777

16. Burnell L, Argan DI. Compassionate care: can it be defined and measured? the development of the compassionate care assessment tool international. Int J Caring Sci. 2013 [cited 2019 Jan 20];6(2):180-7. Available from: https://pdfs. semanticscholar.org/874c/8c46959696def1a572909da29e1f07d33b59.pdf?_ ga $=2.9896369 .5402776 .1566832584-1813756722.1562699716$

17. Melhem GAB et al. Nurses' perceptions of spirituality and spiritual care giving: a comparison study among all health care sectors in Jordan. Indian J Palliat Care. 2016;22(1):42-9. doi: https://doi.org/10.4103/0973-1075.173949

18. Misko MD, Santos MR, Ichikawa CRF, Lima RAG, Bousso RS. The family's experience of the child and/or teenager in palliative care: fluctuating between hope and hopelessness in a world changed by losses. Rev LatinoAm Enfermagem. 2015;23(3):560-7. doi: https://doi.org/10.1590/01041169.0468 .2588

19. Vilalta A, Valls J, Porta J, Vinãs J. Evaluation of spiritual needs of patients with advanced cancer in a palliative care unit. J Pall Med. 2014;17(5):592-600, doi: https://doi.org/10.1089/jpm.2013.0569

20. Brémault-Phillips S, Olson J, Brett-MacLean P, Oneschuk D, Sinclair S, Magnus $\mathrm{R}$, et al. Integrating spirituality as a key component of patient care. Religions. 2015;6(2):476-98. doi: https://doi.org/10.3390/rel6020476

21. Arrieira ICO, Thoferhn MB, Schaefer OM, Fonseca AD, Kantorski LP, Cardoso $D H$. The sense of spiritual care in the integrality of attention in palliative care. 2017. Rev Gaúcha Enferm. 38(3):e58737. doi: https://doi.org/10.1590/19831447.2017.03.58737

22. Freitag VL, Andrade A, Badke MR. 0 Reiki como forma terapêutica no cuidado à saúde: uma revisão narrativa da literatura. Enferm. Global. 2015;38:346-56. doi: https://doi.org/10.6018/eglobal.14.2.200511

23. Taylor EJ, Gober-ParkC, Schoonover-Shoffner K, Mamier I, Somaiya CK, Bahjri K. Nurse opinions about initiating spiritual conversation and prayer in patient care. J Adv Nurs. 2018;74:2381-2392. https://doi.org/10.1111/jan.13777

\section{- Corresponding author:}

Marta Georgina Oliveira de Góes

E-mail:mgogoes@gmail.com

\section{Associate editors:}

Aline Marques Acosta

Cecília Helena Glanzner

Received: 05.02.2019

Approved: 08.13.2019
Editor-in-chief:

Maria da Graça Oliveira Crossetti 